\title{
Disinfectious Effect of Ozonation on Water Infested with Several Root-Infecting Pathogens
}

\author{
Hiroki Yamamoto*, Toshiro Terada**, Takahiko Naganawa* \\ and Kadzunori TATSUYAMA*
}

Key words: hydroponic culture, water disinfection, ozonation, root-infecting pathogen.

As the use of hydroponic culture to grow vegetables (e.g. tomatoes, lettuce) has increased, so too have problems with root-infecting pathogens responsible for some business failures. Although, proper disinfection procedures should prevent this, several root-infecting pathogens have been reported on vegetables in recirculating hydroponic systems ${ }^{1,2}$.

Ozone, as a disinfectant to purify drinking water, came into use in 1906 in France, and since has been adopted by more than 1,000 facilities throughout Europe ${ }^{3)}$. In North America, interest in ozone is increasing as a result of a need to reduce levels of chlorine in water treatment, in keeping with legislated maximum contaminant levels for trihalomethanes ${ }^{4}$.

In this paper, the authors examined the effect of ozonation on several common root-infecting pathogens to determine whether ozonation is suitable for disinfection of source water for hydroponic solutions.

Test organisms. Plant pathogens tested in this experiment were as follows:

Corynebacterium michiganense pv. michiganense (E.F. Smith) Jensen (Strain 4)

Pseudomonas solanacearum E.F. Smith (Strain P1-18-1)

Erwinia carotovora subsp. carotovora (Townsend) Holland (Strain E7105)

Fusarium oxysporum Schlechtendahl f. sp. lycopersici (Saccardo) Snyder (Strain SU-72)

Ozonation and viable cell count. The test organisms were incubated with shaking at $25 \mathrm{C}$ in PS medium (decoction of $200 \mathrm{~g}$ of potato, $30 \mathrm{~g}$ of sucrose, 1 liter of distilled water) for 3 days. The bacterial cells were harvested by centrifugation $(2,000 \times g, 10 \mathrm{~min})$ and washed twice with sterile distilled water. The microconidia-like budding cells of $F$. oxysporum were filtered with sterile gauze to remove filamentous mycelia, and harvested as above. The respective harvested cells were suspended at a density of $5 \times 10^{3}-5 \times 10^{4}$ cells $/ \mathrm{ml}$ solution (determined with a hemocytometer) in 10 liter of autoclaved salts solution in stainless steel tank $(45 \mathrm{~cm} \mathrm{~h} . \times 25$ $\mathrm{cm}$ dia.) with a narrow top opening $\left(5 \mathrm{~cm}\right.$ dia.). The solution contained $0.2 \mathrm{~g}$ of $\mathrm{MgSO}_{4} \cdot 7 \mathrm{H}_{2} \mathrm{O}$, $0.5 \mathrm{~g}$ of $\mathrm{NH}_{4} \mathrm{H}_{2} \mathrm{PO}_{4}, 0.9 \mathrm{~g}$ of $\mathrm{KNO}_{3}, 0.8 \mathrm{~g} \mathrm{Ca}\left(\mathrm{NO}_{3}\right)_{2}, 0.1 \mathrm{mg}$ of $\mathrm{CuSO}_{4} \cdot 5 \mathrm{H}_{2} \mathrm{O}, 0.2 \mathrm{mg}$ of $\mathrm{ZnSO}_{4} \cdot$ $7 \mathrm{H}_{2} \mathrm{O}, 0.02 \mathrm{mg}$ of $\mathrm{Na}_{2} \mathrm{MoO}_{4}, 2 \mathrm{mg}$ of $\mathrm{MnCl}_{2} \cdot 4 \mathrm{H}_{2} \mathrm{O}, 3 \mathrm{mg}$ of $\mathrm{H}_{3} \mathrm{BO}_{3}, 20 \mathrm{mg}$ of Fe-EDTA in 1 liter of distilled water. The suspension was ozonated at a rate of $10 \mathrm{liter} / \mathrm{min}$ using a ozone generator (Fujimori Sangyo Co., Ltd. OZW-MN200, cold plasma discharge method). The control suspension was aerated at the same flow rate. A portion of the suspension was sampled after $0,15,30,60,90$ and $120 \mathrm{~min}$ ozonation or aeration, and diluted adequately with sterile distilled water. The diluted suspension was plated onto PS agar medium and incubated at 28 C. After 3 days, colonies appearing on the agar plates were counted, and the number of viable cells in the suspension at the time of sampling was estimated from the count.

\footnotetext{
* Faculty of Agriculture, Shimane University, Matsue 690, Japan 島根大学農学部

** Matsue Hydroponic Culture Farm, Nagae, Matsue 690, Japan 松江水耕農場

1) Daughtrey, M.L. and Schippero, P.A. (1980). Acta Hortic. 98: 283-291. 2) Davies, J.M.L. (1980). Ibid. 98: 299-305. 3) Rice, R.G. (1985). In Safe Drinking Water (Rice, R.G. ed.). Lewis Publishers, Chelsea. pp. 123-159. 4) Glaze, W.H. (1987). Environ. Sci. Technol. 21: 224-230.
} 


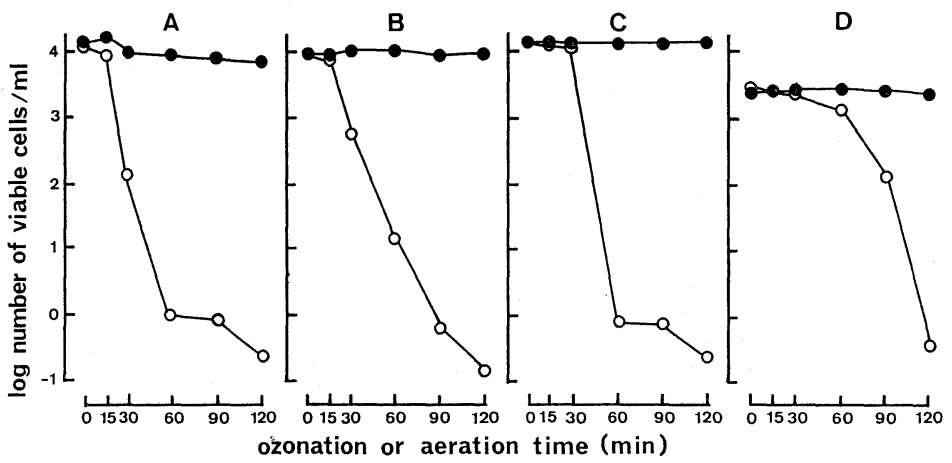

Fig. 1. Changes in viable cell number of Corynebacterium michiganense (A), Erwinia carotovora (B), Pseudomonas solanacearum (C) and Fusarium oxysporum (D) in the solution accompanying ozonation (open circle) and aeration (solid circle).

Figure 1 shows changes in viable cell number accompanying ozonation and aeration of $C$. michiganense, E. carotovora. $P$. solanacearum and $F$. oxysporum. In no case did aeration changed the viable cell number in the suspension during the test periods, while ozonation decreased the viable cell number immediately. Sixty min ozonation for $C$. michiganense and $P$. solanacearum, $90 \mathrm{~min}$ for $E$. carotovora and $120 \mathrm{~min}$ for $F$. oxysporum reduced the respective number of viable cells in the suspension to $1 \mathrm{cell} / \mathrm{ml}$ or less. The sensitivity to ozonation of $F$. oxysporum, the only fungus among the tested organisms, was less than that of the bacteria, but after ozonation for $120 \mathrm{~min}$, the survival of the fungus was nearly zero. In this experiment, however, microconidia-like budding cells were used as a fungal inoculum. Chlamydospores could possibly require longer ozonation treatment to be completely sterilized.

The authors express appreciation to Dr. Tsugio Sasaki, Morioka Branch, Vegetables and Ornamental Crops Research Station, and Prof. Dr. Yuichi Honda, Faculty of Agriculture, Shimane University, for providing the bacterial strains. The authors wish to thank Prof. Dr. David Hosford, Department of Biological Sciences, Central Washington University, for his critical reading of the manuscript, and Prof. Dr. Yoshihisa Matsui, Faculty of Agriculture, Shimane University, for his valuable advice.

\section{和 文 摘 要}

山本広基・寺田俊郎・長縄貴彦・達山和紀 : 土壌伝染性植物病原菌を混入した試水のオゾンによる消毒

水耕液として使用する水の消毒手段としてのオゾン処理の適否を検討する目的で，水 $(101)$ に $5 \times 10^{3}$ $5 \times 10^{4} / \mathrm{ml}$ となるように混入した Corynebacterium michiganense, Erwinia carotovora, Pseudomonas solana. cearum あるいは Fusarium oxysporum f. sp. lycopersici の生存に及洔すオン゙ン処理の影響を試験した。水中 のC. michiganense 打よび P. solanacearumは 60 分間の, E. carotovora は 90 分間の，そして F. oxysporum は 120 分間のオゾン曝気 $(10 \mathrm{l} / \mathrm{min})$ によってほとんど検出されなくなる程度まで減少した。

(Received August 30, 1989) 